Journal of N.G.S. Vol. 7., 1991 Special issue 59-80

\title{
GEOLOGY AND STRUCTURAL EVOLUTION IN THE BHERI RIVER REGION, SOUTHWEST NEPAL.
}

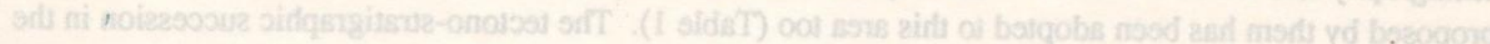

\author{
D. R. Kansakar \\ Department of Mines \& Geology, Kathmandv
}

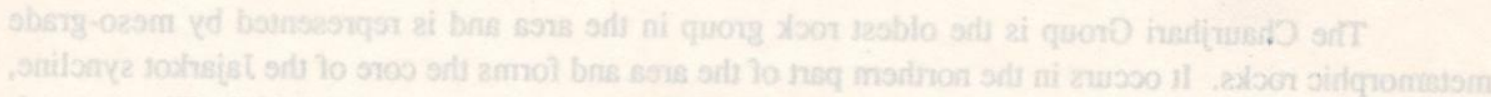

ABSTRACT

The rocks of the Lesser Himalaya in the Bheri River region have been divided into five stratigraphic groups. The meso-grade metamorphic rocks of the Chaurjhari Group is the oldest rock group in the area and is occurring as a klippen in the north. The Kunchha Group and the Nawakot Group are the incipiently metamorphosed sedimentary rocks while the Gondwana Group and Daban Group rocks are generally unmetamorphosed sedimentary sequences.
\end{abstract}

In the frontal part of the thrust-fold belt of the Himalaya, leading imbricate fan structure is developed in the rocks of Daban Group with the Main Boundary Thrust (MBT) as the sole thrust, and the Kumak Thrust as the roof thrust. In the region further north, a complex of hinterland dipping duplex structure is envisioned between the Kumak Thrust (main sole thrust) and the Chaurjhari Thrust (main roof thrust) with a number of intermittent thrust-faults which acted as roof thrust to the underlying duplex-and as sole thrust to the overlying duplex. The major planes of detachment for the generation of duplex are postulated along the incompetent basal rock members of the Nawakot Group, the Kunchha Group and the Chaurjhari Group respectively. As against the view of some of the earlier workers, a "piggy-back" sequence of thrust from higher to lower (hinterland towards the foreland) is proposed.

\section{INTRODUCTION}

The Bheri River region has been traversed by a number of workers in the past, but the stratigraphic and tectonic pictures are still far from being clear. While the partially fossiliferous sedimentary sequence occuring just north of the Main Boundary Thrust (MBT) possesses little difficulty in constructing their stratigraphic set up, a vast area lying in the north consists of unfossiliferous metasedimentary successions. The former is considered to constitute a paratochthonous zone (Hagen, 1969; Fuchs and Frank, 1970; Arita et al, 1984 and Sharma et al, 1984). The tectonic construction of the rocks north of this zone has remained a subject of open discussion till this date. Based on a detailed geological map prepared under the regional geological mapping program of the Department of Mines and Geology by the present author (Kansakar \& Chitrakar, 1982, 1983) and his colleagues (Adhikari and Sharma, 1983), this paper briefly presents the geologic set up, stratigraphy and the structural evolution of the region in the light of the thin skinned tectonic model. 


\section{STRATIGRAPHY}

The present area lies to the west of the area discussed by Sharma et al (1984). Since the stratigraphy and tectonic units described by them could be continued to the present area, the stratigraphy proposed by them has been adopted to this area too (Table 1). The tectono-stratigraphic succession in the area is given in Table 2.

\section{CHAURJHARI GROUP}

The Chaurjhari Group is the oldest rock group in the area and is represented by meso-grade metamorphic rocks. It occurs in the northern part of the area and forms the core of the Jajarkot syncline, which is the western continuation of the Jaljala syncline described by Sharma et al (1984). The two rock formations constituting this group are on the Lower Chaurjhari Formation and the Upper Thabang Formation. The former is a dominantly pelitic and psammitic sequence whereas the latter is mainly a carbonate formation. The rocks show a general trend of decreasing metamorphism from lower to the upper part. This rock group is tectonically emplaced over the Kunchha Group rocks and the thrust contact is a well defined one (Fig. 1).

\section{Chaurihari Formation}

This is the oldest rock formation in the study area. It is exposed in a large area around the Jajarkot syncline in the northern part of the study area.

The major rock types constituting this rock formation are the medium grained crystalline muscovite-biotite-quartz schists, which are often garnetiferous. Interbedded in the schists are the light gray colored quartzites and micaceous quartzites. At places, a few metres thick bands of graphitic schists are seen. The quartzites are generally thin, but some bands as thick as $30 \mathrm{~m}$ are encountered in some sections.

In the Lyure Khola section, the mica schists constituting the lower part of this formation is noted to be calcareous and lenses and bands (up to $15-20 \mathrm{~m}$ ) of crystalline limestone and dolomitic limestone are observed in the schists. Such rocks are seen in the area east of Dhaira village only.

In the Jajarkot syncline area, the base of the Chaurjhari Formation is marked by a 5 to $45 \mathrm{~m}$ thick continuous sheet of blasto-mylonitic augen gneiss. It is conformable to the overlying schists in most sections, but Adhikari and Sharma (1983) reported oblique relationship with the overlying quartzite beds in the northern flank of Jajarkot syncline. Under the microscope, augen shaped porphyroblasts of Kfelspar and albite are seen enclosed by biotite, muscovite and sericite, which define the gneissosity. At places obliquely oriented felspar porphyroblasts are also noted. The effects of shearing are commonly observed and retrogression of biotite into chlorite are also noted. A detailed petrographic and petrochemical study has led Sharma and Kizaki (1988) to conclude that these gneissic rocks are the pre- 
Table 1. LITHOSTRATIGRAPHY OF THE BHERI RIVER REGION.

\begin{tabular}{|c|c|c|c|}
\hline Group & Formation & Lithology & Age \\
\hline Siwalik group & 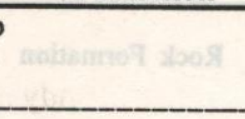 & $\begin{array}{l}\text { Sandstone, Shale, Claystone, } \\
\text { Marl and Conglomerate. }\end{array}$ & $\begin{array}{l}\text { Miocene- } \\
\text { Pleinstocene }\end{array}$ \\
\hline $\begin{array}{l}\text { D } \\
\text { A } \\
\text { B } \\
\text { A }\end{array}$ & $\begin{array}{l}\text { BHAINSEKATTI } \\
\text { FORMATION } \\
(100 \mathrm{~m})\end{array}$ & $\begin{array}{l}\text { Grey, creamy nummulitic limestone and } \\
\text { grey, green grey shale with lenses and bands } \\
\text { of dark grey fossiliferous limestone. }\end{array}$ & $\begin{array}{l}\text { Lower Eocene- } \\
\text { Mid. Eocene }\end{array}$ \\
\hline $\mathbf{N}$ & $\begin{array}{l}\text { AMILE } \\
\text { FORMATION }\end{array}$ & $\begin{array}{l}\text { Grey white orthoquartzite, ferruginous quartzite with } \\
\text { intercalations of carbonaceous shale and coal seams. } \\
\text { conglomerate beds in some sections. }\end{array}$ & $\begin{array}{l}\text { Jurassic- } \\
\text { Cretaceous }\end{array}$ \\
\hline $\begin{array}{l}\mathbf{R} \\
\mathbf{O}\end{array}$ & $(125 \mathrm{~m})$ & UNCONFORMITY & 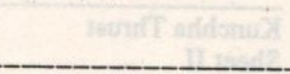 \\
\hline $\begin{array}{l}\mathrm{U} \\
\mathrm{P}\end{array}$ & $\begin{array}{l}\text { GOYALTHAM } \\
\text { FORMATION } \\
(3100 \mathrm{~m})\end{array}$ & $\begin{array}{l}\text { White, cream and bluish grey limestone and dolomite } \\
\text { intercalations of variecolored shale and sandstone. } \\
\text { Domal stromatolites present. Contains intraforma- } \\
\text { tional breccia, ripple marks and mud cracks. }\end{array}$ & . Permo-Triassic \\
\hline & $\begin{array}{l}\text { KOCHHAP } \\
\text { FORMATION } \\
(1700 \mathrm{~m}+)\end{array}$ & $\begin{array}{l}\text { Yellowish brown, green grey and dark grey laminated } \\
\text { and shaly slate with grey white sandstone and white, } \\
\text { blue grey limestone and dolomite. Diamictite of few } \\
\text { metre thick in some sections. Ripple mark and mud } \\
\text { crack seen. }\end{array}$ & $\begin{array}{l}\text { Permo- } \\
\text { Carboniteferous }\end{array}$ \\
\hline \multicolumn{2}{|c|}{$\begin{array}{lc}\text { GONDWANA } & \text { PHALABANG } \\
\text { GRORMATION } & (330 \mathrm{~m}+)\end{array}$} & $\begin{array}{l}\text { Black carbonaceous shale. A } 60 \mathrm{~m} \text {. thick light brown } \\
\text { weathering dark grey sandstone at the base. }\end{array}$ & Lower Permian \\
\hline & $\begin{array}{c}\text { SALLYAN } \\
\text { FORMATION } \\
(700 \mathrm{~m}+)\end{array}$ & $\begin{array}{l}\text { Conglomeratic phyllite } \\
\text { UNCONFORMITY/THRUST }\end{array}$ & $\begin{array}{l}\text { Permo- } \\
\text { carboniferous }\end{array}$ \\
\hline $\begin{array}{l}\text { NAWAKOT } \\
\text { GROUP }\end{array}$ & $\begin{array}{l}\text { KUMAK } \\
\text { FORMATION } \\
(1100 \mathrm{~m}+)\end{array}$ & $\begin{array}{l}\text { Bluish grey and light blue limestone and dolomitic } \\
\text { limestone with columnar stromatolite. Dark grey, } \\
\text { green and silvery grey phyllite and white to bluish } \\
\text { grey sericite qzt. at the base. }\end{array}$ & $\begin{array}{l}\text { Late- } \\
\text { Precembrian }\end{array}$ \\
\hline \multirow[t]{2}{*}{$\begin{array}{l}\text { KUNCHHA } \\
\text { GROUP }\end{array}$} & $\begin{array}{l}\text { KUNCHHA } \\
\text { FORMATION }\end{array}$ & $\begin{array}{l}\text { Grey green phyllite, gritty phyllite, quartzite and } \\
\text { gritty to rarely conglomeratic quartzite. Intrusive } \\
\text { metabasic rocks profusely present. }\end{array}$ & Pre-Cambrian \\
\hline & $\begin{array}{l}\text { THABANG } \\
\text { FORMATION }\end{array}$ & Crystalline limestone or marble and calcareous schist & $\begin{array}{l}\text { Pre- } \\
\text { Cambrian }\end{array}$ \\
\hline $\begin{array}{l}\text { GHAURJHAR } \\
\text { GROUP }\end{array}$ & $\begin{array}{l}\text { CHAURJHARI } \\
\text { FORMATION }\end{array}$ & $\begin{array}{l}\text { Garnet mica schist, muscovite-biotite schist with } \\
\text { micaceous quartzite and felspathic schist. Garneti- } \\
\text { ferous calc-schist, crystalline limestone in the Lyure } \\
\text { khola. Granitoid rocks at places. }\end{array}$ & $\begin{array}{l}\text { Pre- } \\
\text { Cambrian }\end{array}$ \\
\hline
\end{tabular}


Table 2. The litho-tectonic succession in the Bheri River region.

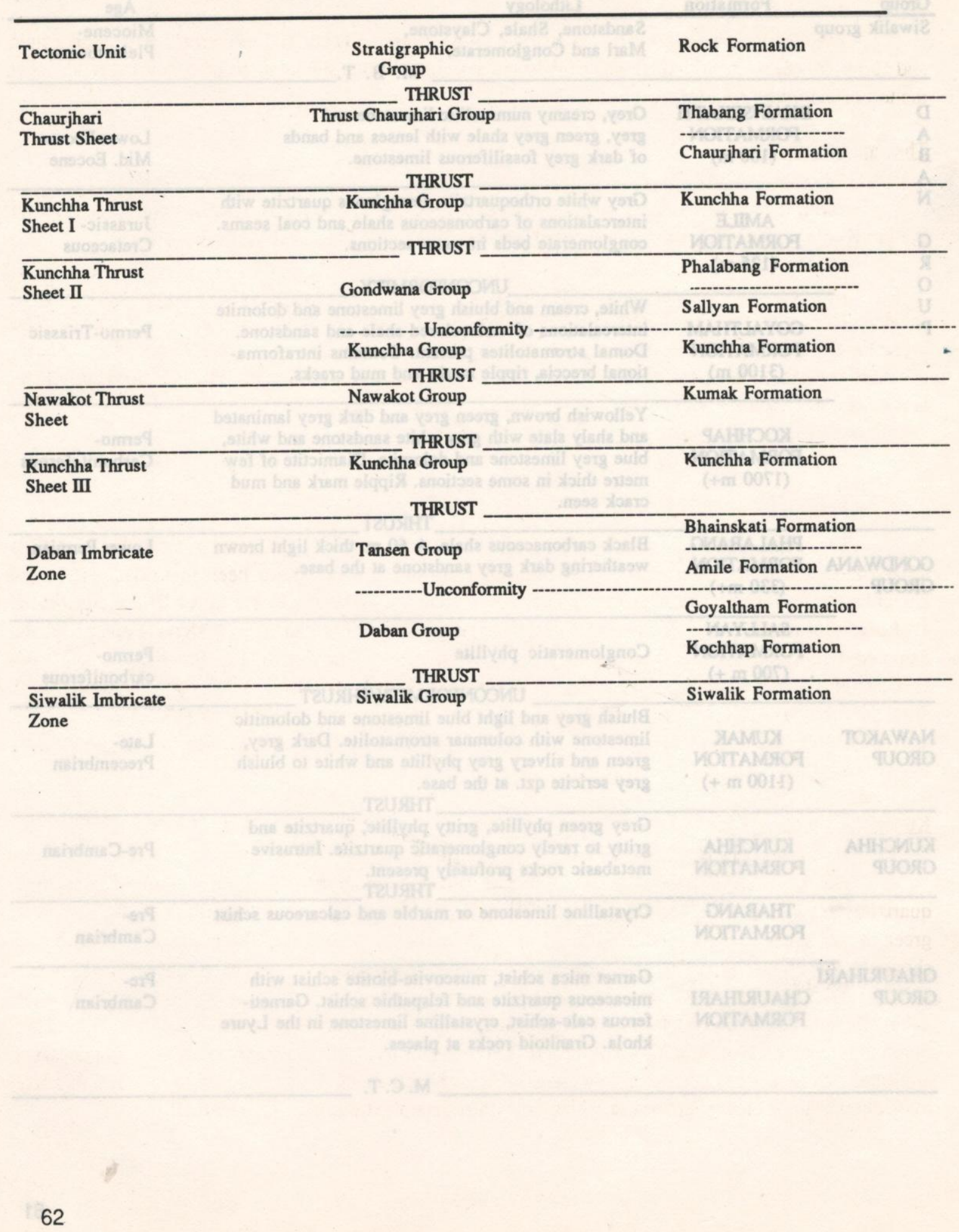


thrusting plutonic granitoid intrusives, later mobilised along the thrust surfaces during thrust movements. They are of the opinion that the gneissic structure and the mineralogical changes are incurred upon the intrusive rocks during the thrust movements.

The Chaurjhari Formation is transitionally overlain by Thabang Formation. In the Jare Khola and Humri Khola sections, a thick bed of light green to light brown slabby micaceous quartzites occurs at the top of the Chaurjhari Formation.

\section{Thabang formation}

Forming the core of the Jajarkot syncline, the rocks of Thabang Formation are well exposed in the Jari Khola section. Isolated occurrences are preserved in the Jagtipur and Mula villages.

The Thabang Formation is represented by crystalline limestone or marble interbedded with mica schists. The rocks are thinly interbedded in the lower part, but becomes thicker in the upper part. The crystalline limestone or marble is gray white, medium to coarsely crystalline int texture. Quartz, muscovite, biotite, garnet and amphibole are the common accessary minerals. The interlayering schists are the two mica schists with garnet porphyroblasts of up to $4 \mathrm{~mm}$ diameter.

\section{KUNCHHA GROUP}

The Kunchha Group rocks are widespread in the study area. It is thrusted over by the crystalline rocks of the Chaurjhari Thrust Sheet. Three different thrust sheets have been identified within the Kunchha Group rocks. The Kunchha Thrust Sheet I and the Kunchha Thrust Sheet III are constituted exclusively of the Kunchha Group rocks. On the other hand, the Kunchha Thrust sheet II comprises the Kunchha Group rocks overlain by the Gondwana Group rocks. The Kunchha Group consists of a thick succession of a monotonous flysch like rock sequence. Although thick beds of gritty quartzites or quartzites can be traced for a considerable strike length, the subdivision of this rock group has been quite difficult. Thus, the rock formation constituting this rock group has been described as the 'Kunchha Formation'.

\section{Kunchha Formation}

The Kunchha Formation consists of flysch-like alternation of phyllites, phyllitic quartzites, quartzites and gritstones of varying thicknesses. The phyllites are generally green, gray and yellowish green in colour and contain sericite and chlorite as the main flaky minerals. The grade of metamorphism shown by Kunchha Formation rocks in various thrust sheets are different from each other. The Kunchha rocks in the Kunchha Thrust Sheet II is least metamorphosed in the Sallyan area. For example, in the Bhun Khola section, yellowish brown shale occurs at the base of the Kunchha Thrust Sheet II, and the overlying rocks are also little metamorphosed. On the other hand, the Kunchha rocks in Suikot, Jajarkot and Bheri River sections belonging to Kunchha Thrust Sheets I and II has been metamorphosed into fine to medium grained biotite-muscovite schists with garnet porphyroblasts of $1-4 \mathrm{~mm}$ diameter. 
The quartzites are mostly white to light gray in colour and are constituted of dominantly sandy to gritty clasts of quartz and occasionally some felspar in a matrix of fine quartz and argillaceous material. In some cases, even conglomeratic pebbles of quartzites are seen forming thin beds in it. Relic sedimentary clastic texture can be frequently identified under a microscope although low grade metamorphic minerals like sericite, chlorite and sometimes muscovite are present. The coarser gritty and conglomeratic quartzites contain sub-rounded, ellipsoidal to flat detritus of mainly white quartz and micaceous quartzite (Plate 1). Such conglomeratic quartzites are observed in Bhiuns Khola section in the north and in Sui Khola and at Ghat and Ranagaon in the Sarda Khola area in the south. The conglomerates at Rita Khola, Sui Khola, Salebang and Harichaur villages contain pebbles of dolomitic limestone together with that of white quartz and micaceous quartzite (Plate 2). In the Bhiuns Gad section, the conglomerate horizon is about $50 \mathrm{~m}$ thick whereas in other sections, they are much thinner. Current bedding and occasionally graded bedding structures are recorded from these quartzite beds (Plate 3 ).

A band of about $10 \mathrm{~m}$ thick bluish gray dolomitic limestone with fine intercalations of argillaceous material has been recorded from this rock formation at the spur near Dangri village, east of Sarda Khola (Plate 4). Its lower contact is sharp but the upper contact is graditional. In this locality, thelimestone shows numerous NNE plunging tight isoclinal folds and also similarly plunging striation lineation.

Intrusive metabasic rocks are prolific in this formation. It is most abundant particularly in the Kunchha Thrust Sheet II and are well exposed in the area around Jhargaon, Chakli Gad and between Surma and Arudanda (Fig. 1 and 2). These basic rocks show concordant as well as discordant relationship with the country rock. They have beien subjected to metamorphism and are in various stages of alteration. Large intrusive bodies still show igneous texture with little change in mineralogy in the core part, but are found to alter into epidiorite and then into green schists towards the margin. It is noted that generally the concordant basic bodies are more metamorphosed than the discordant bodies. Again, the basic intrusives occurring near the tectonic contacts are often altered into green schists. A prominent layer of such metabasic green schist is observed all along the thrust contact with the overlying Kumak Formation in the Chakli Gad area (Fig. 2 and 3).

\section{NAWAKOT GROUP}

The Nawakot Group is only partially represented in the Bheri River region. A dominant carbonate rock formation best developed in the Kumak area and Sarda Khola section north of Sallyan represents the upper carbonate horizon of Hatiya Formation of Sharma et al (1984). Since it forms only a part of the Hatiya Formation, this rock horizon has been given a local name 'Kumak Formation'. The Kumak Formation has its upper as well as lower contact defined by well developed thrusts and thus constitutes a separate thrust sheet (Fig. 1).

\section{Kumak Formation}

This rock formation is best developed in the Kumak area and hence the name 'Kumak Formation'. It is also well exposed at Madamgaur and Sarda Khola section at the north of Sallyan. It has 


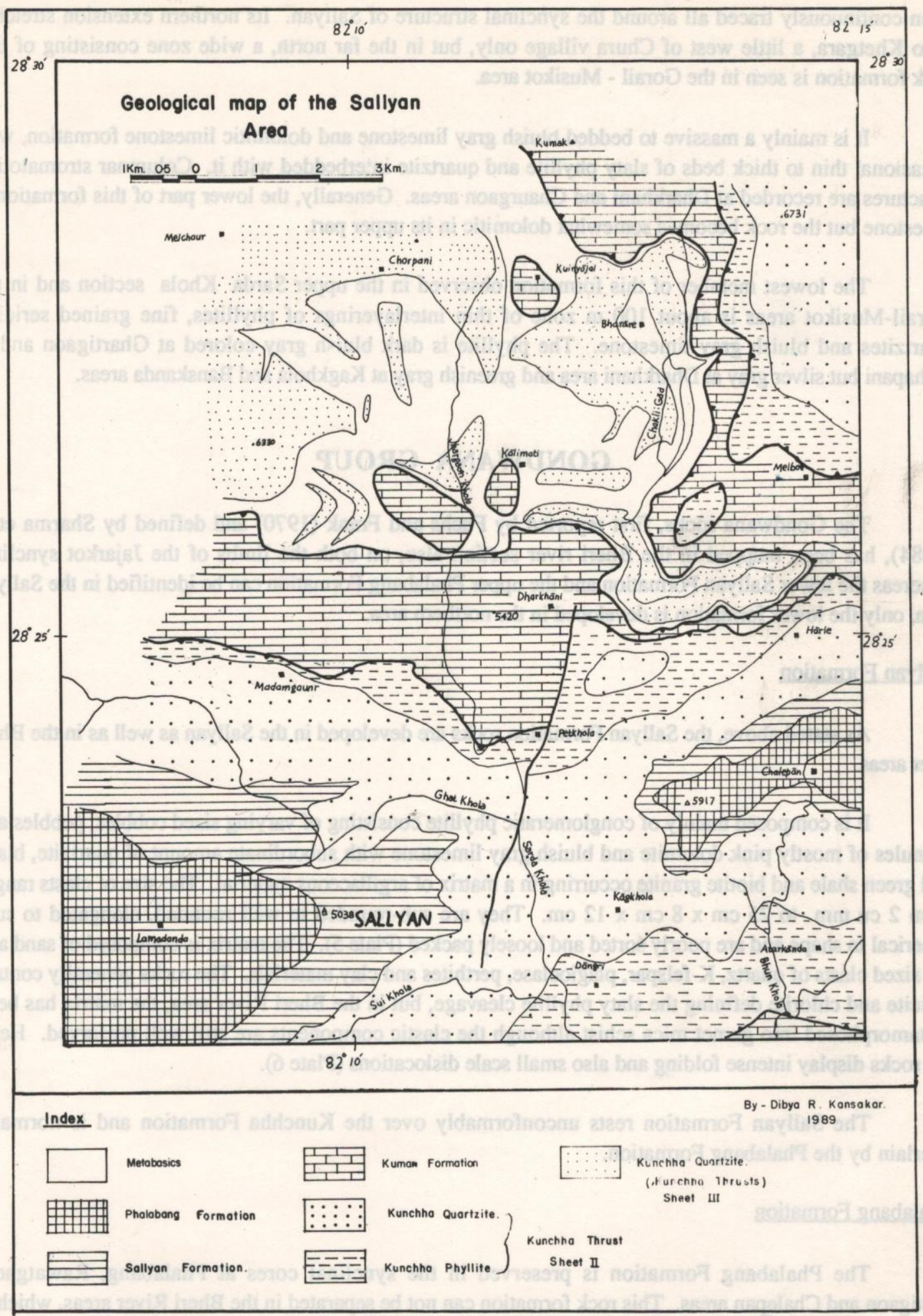


been continuously traced all around the synclinal structure of Sallyan. Its northern extension stretches upto Khetgara, a little west of Chura village only, but in the far north, a wide zone consisting of this rock formation is seen in the Gorail - Musikot area.

It is mainly a massive to bedded bluish gray limestone and dolomitic limestone formation, with occasional thin to thick beds of slaty phyllite and quartzite interbedded with it. Columnar stromatolitic structures are recorded at Dharkhani and Chaurgaon areas. Generally, the lower part of this formation is limestone but the rock becomes somewhat dolomitic in its upper part.

The lowest member of this formation observed in the upper Sarda Khola section and in th Gorail-Musikot areas is about $100 \mathrm{~m}$ zone of thin interlayerings of phyllites, fine grained serici: quartzites and bluish gray limestone. The phyllite is dark bluich gray colored at Ghartigaon and Rithapani but silver gray at Dharkhani area and greenish gray at Kagkhola and Banskanda areas.

\section{GONDWANA GROUP}

The Gondwana rocks, first reported by Fuchs and Frank (1970) and defined by Sharma et al (1984), has been mapped in the Bheri river section also, on both the limbs of the Jajarkot syncline. Whereas the lower Sallyan Formation and the upper Phalabang Formation can be identified in the Sallyan area, only the lower formation is developed in the northern area.

\section{Sallyan Formation}

As stated above, the Sallyan Formation rocks are developed in the Sallyan as well as in the Bheri river areas.

It is composed mainly of conglomeratic phyllite consisting of varying sized cobbles, pebbles and granules of mostly pink dolomite and bluish gray limestone with subordinate amount of quartzite, black and green shale and biotite granite occurring in a matrix of argillaceous material. The size of clasts ranges from $2 \mathrm{cu} \mathrm{mm}$ to $25 \mathrm{~cm} \times 8 \mathrm{~cm} \times 12 \mathrm{~cm}$. They are sub-rounded to well rounded, elongated to subspherical in shape and are poorly sorted and loosely packed (Plate 5). The matrix is composed of sand and silt sized clasts of quartz, K-felspar, plagioclase, perthites and clay materials. The rocks generally contain sericite and chlorite defining the slaty phyllite cleavage, but in the Bheri River area, the matrix has been metamorphosed into garnet mica schist although the clastic components are still well preserved. Here, the rocks display intense folding and also small scale dislocations (Plate 6).

The Sallyan Formation rests unconformably over the Kunchha Formation and is normally overlain by the Phalabang Formation.

Phalabang Formation

The Phalabang Formation is preserved in the synclinal cores at Phalabang, Rawatgaon, Ranigaon and Chalepan areas. This rock formation can not be separated in the Bheri River areas, which is 


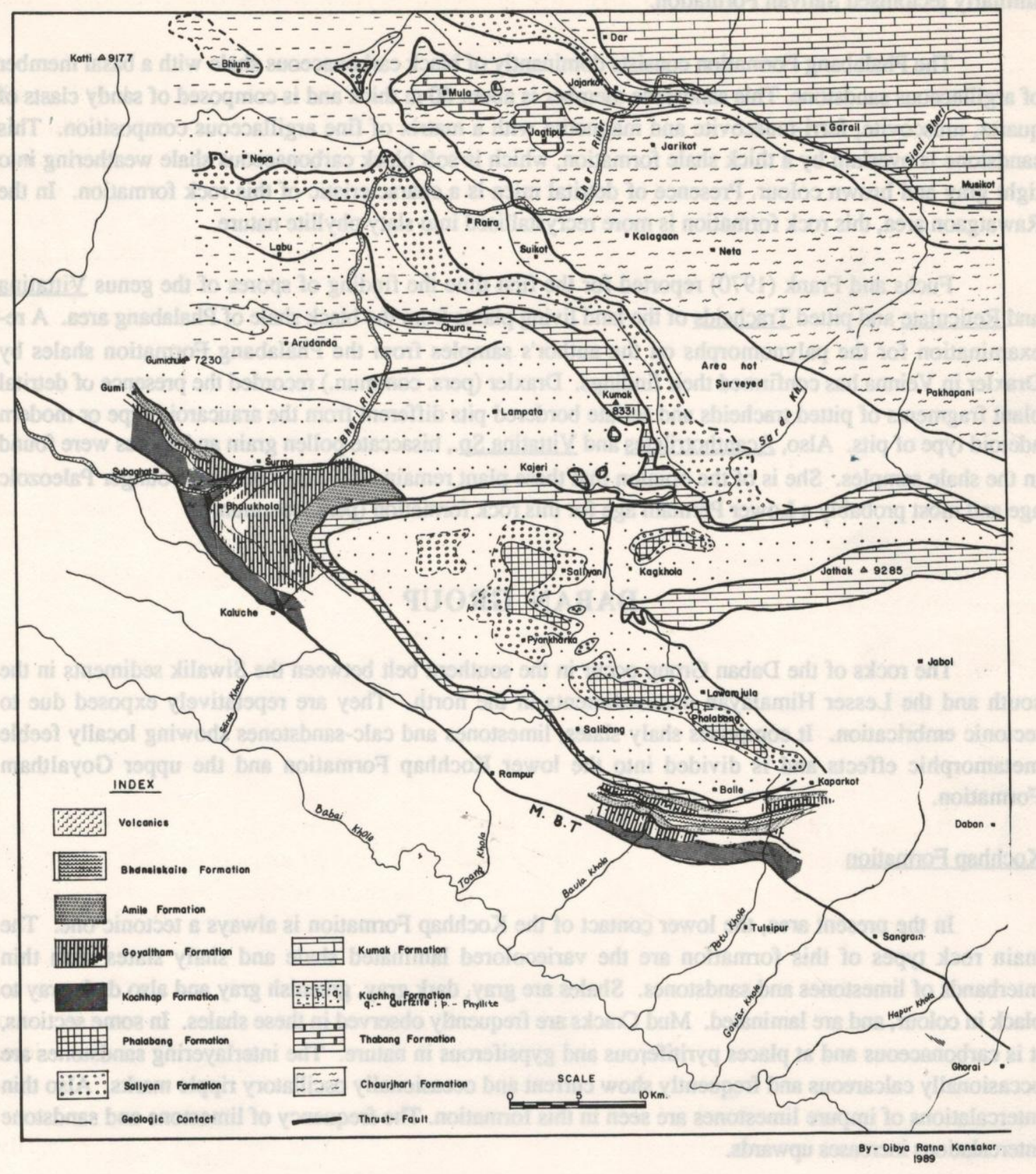


either not developed or has been highly tectonised making its appearance difficult to distinguish from the similarly tectonised Sallyan Formation.

The Phalabang Formation consists dominantly of black carbonaceous shale with a basal member of argillaceous sandstone. This sandstone member is about $60 \mathrm{~m}$ thick and is composed of sandy clasts of quartz, muscovite, ferri-muscovite and magnetite with a matrix of fine argillaceous composition. This sandstone is overlain by a thick shale formation, which is soft black carbonaceous shale weathering into light gray and brown colour. Presence of detrital mica is a characteristic of this rock formation. In the Rawatgaon area, this rock formation is more recrystallised into slaty phyllite nature.

Fuchs and Frank (1970) reported for the first time the finding of spores of the genus Vittatina and Reticulate and pitted Tracheids of the land living plants from the black shale of Phalabang area. A reexamination for the palynomorphs on the author's samples from the Phalabang Formation shales by Draxler in Veinna has confirmed their findings. Draxler (pers. commun.) recorded the presence of detrital plant fragments of pitted tracheids and seriate bordered pits different from the araucaroid type or modern adetoid type of pits. Also, Acanthotriletes and Vittatina Sp., bisaccate pollen grain and spores were found in the shale samples. She is of the opinion that these plant remains indicate a definite younger Paleozoic age and most probably a Lower Permain age for this rock formation (pers. commun.).

\section{DABAN GROUP}

The rocks of the Daban Group occur in the southern belt between the Siwalik sediments in the south and the Lesser Himalayan metasediments in the north. They are repetatively exposed due to tectonic embrication. It comprises shaly slates, limestones and calc-sandstones showing locally feeble metamorphic effects and is divided into the lower Kochhap Formation and the upper Goyaltham Formation.

\section{Kochhap Formation}

In the present area, the lower contact of the Kochhap Formation is always a tectonic one. The main rock types of this formation are the variecolored laminated shale and shaly slates with thin interbands of limestones and sandstones. Shales are gray, dark gray, greenish gray and also dark gray to black in colour, and are laminated. Mud Cracks are frequently observed in these shales. In some sections, it is carbonaceous and at places pyritiferous and gypsiferous in nature. The interlayering sandstones are occasionally calcareous and frequently show current and occasionally oscillatory ripple marks. Also thin intercalations of impure limestones are seen in this formation. The frequency of limestone and sandstone intercalations increases upwards.

\section{Goyaltham Formation}

The Goyaltham Formation is dominantly a carbonate sequence with subordinate shale and sandstone interbeddings. The basal member is a thick sequence of dominantly sandstones with close intercalations of purple, greenish gray to gray shales and gray dolomites. Over the basal member occurs a 


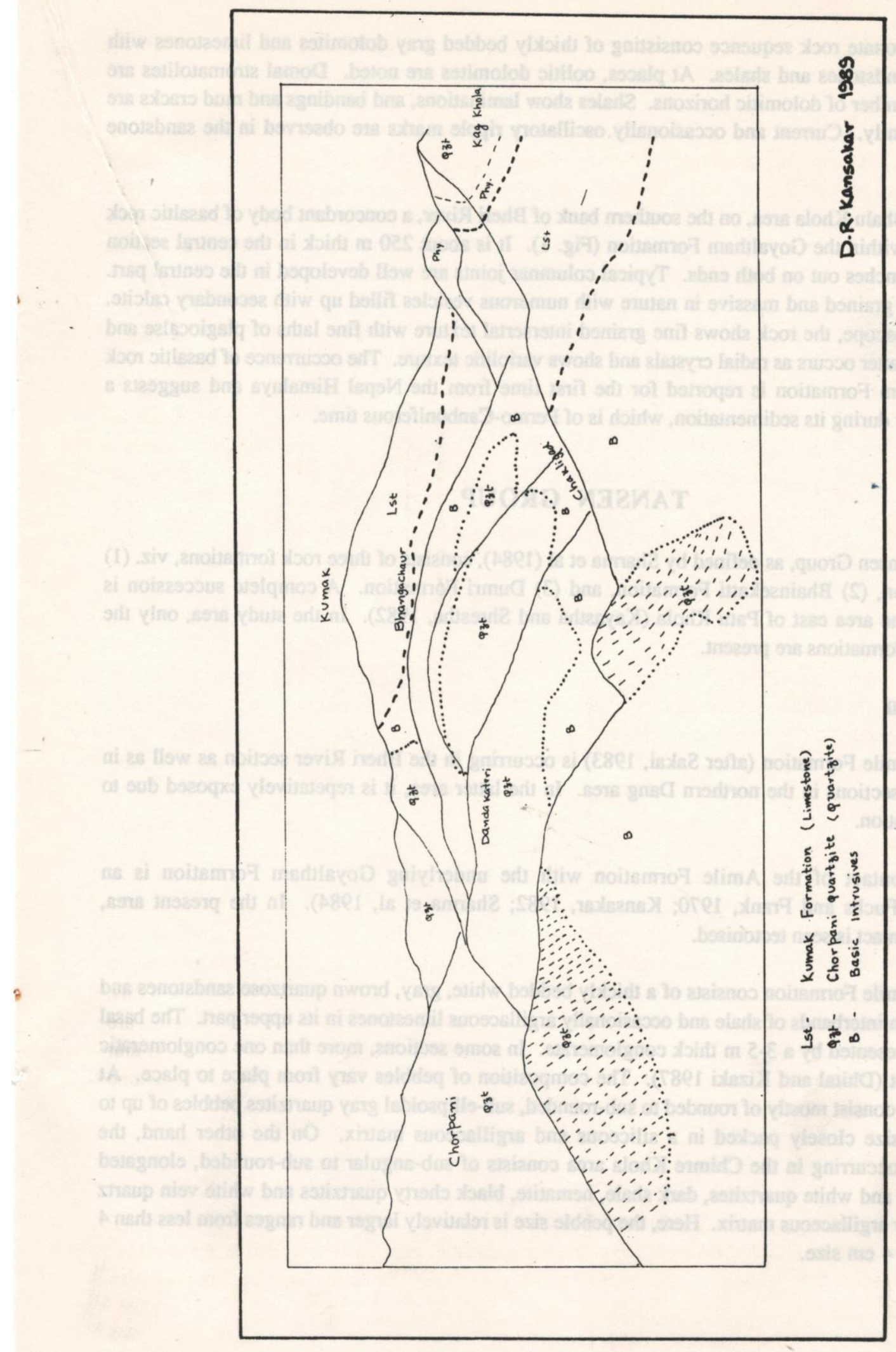


dominantly carbonate rock sequence consisting of thickly bedded gray dolomites and limestones with interlayers of sandstones and shales. At places, oolitic dolomites are noted. Domal stromatolites are observed in a number of dolomitic horizons. Shales show laminations, and bandings and mud cracks are observed frequently. Current and occasionally oscillatory ripple marks are observed in the sandstone layers (Plate 7).

In the Bhalu Khola area, on the southern bank of Bheri River, a concordant body of basaltic rock is encountered within the Goyaltham Formation (Fig. 1). It is about $250 \mathrm{~m}$ thick in the central section and gradually pinches out on both ends. Typical columnar joints are well developed in the central part. The rock is fine grained and massive in nature with numerous vesicles filled up with secondary calcite. Under the microscope, the rock shows fine grained intersertal texture with fine laths of plagiocalse and pyroxene. The latter occurs as radial crystals and shows variolitic texture. The occurrence of basaltic rock in the Goyaltham Formation is reported for the first time from the Nepal Himalaya and suggests a volcanic activity during its sedimentation, which is of Permo-Canboniferous time.

\section{TANSEN GROUP}

The Tansen Group, as defined by Sharma et al (1984), consists of three rock formations, viz. (1) Amile Formation, (2) Bhainsekatti Formation, and (3) Dumri Formation. A complete succession is reported from the area east of Patu Khola (Kayastha and Shrestha, 1982). In the study area, only the lower two rock formations are present.

\section{Amile Formation}

The Amile Formation (after Sakai, 1983) is occurring in the Bheri River section as well as in various stream sections in the northern Dang area. In the latter area, it is repetatively exposed due to tectonic embrication.

The contact of the Amile Formation with the underlying Goyaltham Formation is an unconformity (Fuchs and Frank, 1970; Kansakar, 1982; Sharma et al, 1984). In the present area, however, the contact is seen tectonised.

The Amile Formation consists of a thickly bedded white, gray, brown quartzose sandstones and graywackes with interbands of shale and occasionally argillaceous limestones in its upper part. The basal part of it is represented by a 3-5 m thick conglomerate. In some sections, more than one conglomeratic beds are present (Dhital and Kizaki 1987). The composition of pebbles vary from place to place. At Harichaur, they consist mostly of rounded to sub-rounded, sub-ellipsoidal gray quartzites pebbles of up to $5 \mathrm{~cm} \times 2 \mathrm{~cm}$ size closely packed in a siliceous and argillaceous matrix. On the other hand, the conglomerates occurring in the Chimre Khola area consists of sub-angular to sub-rounded, elongated pebbles of gray and white quartzites, dark shale, hematite, black cherty quartzites and white vein quartz held together by argillaceous matrix. Here, the pebble size is relatively larger and ranges from less than 4 $\mathrm{mm}$ to $10 \mathrm{~cm} \mathrm{x} 4 \mathrm{~cm}$ size. 


\section{Bhainsékatti Formation}

The Bhainsekatti Formation occurs in the Bhamke Khola section in the northern Dang area. It is an important rock formation owing to its fossil content.

It is dominantly a shale formation with pink shaly limestone interbandings in its upper part. The shales are greenish gray to dark gray and pink in colour and contain lenses and bands of dark gray and pink fossiliferous limestones.

Numerous nummulites and assilina fossils have been reported from these calcareous rocks (Kayastha and Shrestha, 1982; Sakai, 1983). The calcareous bands in the upper sections of the formation are rich in gastropod and pelecypod fossils (Kayastha and Shrestha, op.cit.). A Lower to Middle Eocene age has been assigned to this rock formation by the earlier workers.

\section{TECTONICS}

The study area belongs to the southern part of the Lesser Himalaya in western Nepal. The various tectonic elements observed in the study area are briefly described and their evolution discussed here.

As we enter the Lesser Himalayan ranges from the Dang Valley (Fig. 4), the Siwalik sediments are seen overthrust by the rocks of Daban Group along the Main Boundary Thrust. Here, the M.B.T. dips at angle ranging from 45 to 60 degree due north-northeast. The sedimentary sequence of Daban Group together with Tansen Group rocks are seen repeatedly exposed due to reverse faulting in the northern Dang area, and shows the typical characters of embricate stacking. But in the Bhalu Khola area, these rocks are folded together with the overlying tectonic units.

The next higher tectonic unit is the Nawakot Thrust Sheet composed entirely of the Kumak Formation in the present area. Its extension to the far south in northern Dang area suggests that they once covered much of the area in Bheri River section now occupied by the Kunchha Formation rocks of the Kunchha Thrust Sheet III. The Nawakot Thrust Sheet is transported over the rocks of Daban and Tansen Groups in the northern Dang area, but lies over the Kunchha Group rocks in the Bheri River section. This thrust sheet has its hindward extension in the Gorail- Musikot area, where it is exposed in a wide zone.

The Kunchha Thrust Sheet III, which is thrusted over the Tansen Group and Daban Group rocks and is itself overthrust by the Nawakot Thrust Sheet, has a unique tectonic situation. It shows an anticlinal fold in the upper Sarda Khola area, near Chaki Gad and here, the attitude of the underlying Kunchha quartzite is seen oblique to that of the overlying Nawakot Thrust Sheet rocks at a number of locations. This provides an important clue to the ramp structure to be discussed later.

The Kunchha Thrust Sheet II, which consists of the Kunchha Group together with the Gondwana Group rocks, occupies an extensive area. The occurrence of quartzitic rocks of this thrust sheet in the 


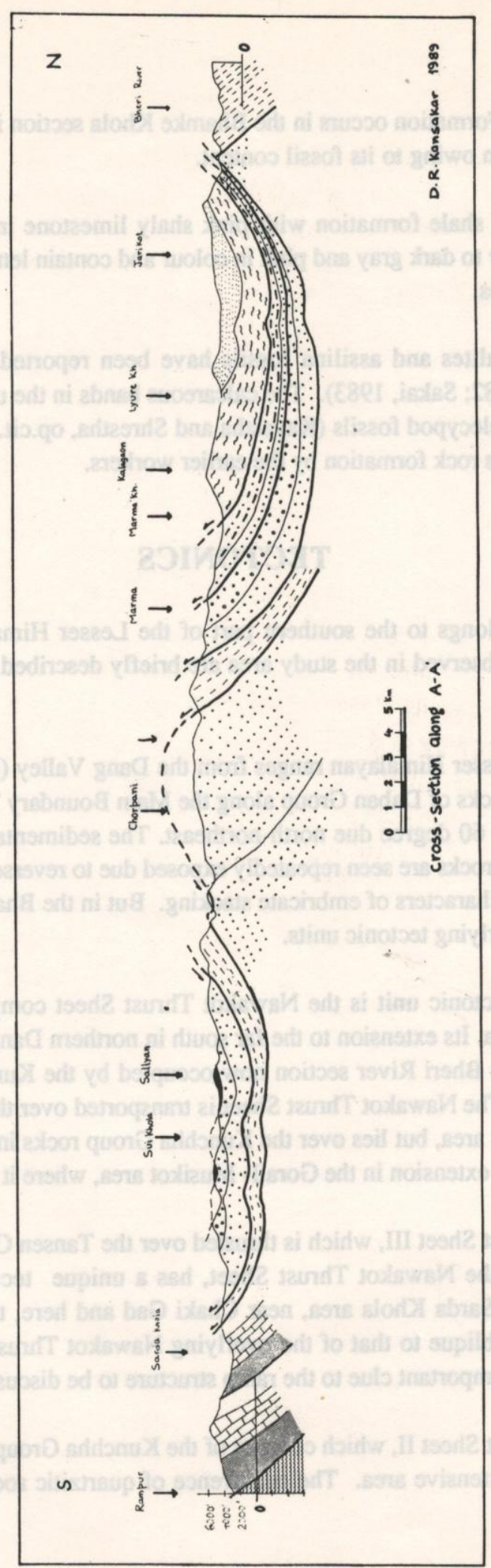

72 
Holleri klippe (Dhital and Kizaki, 1987) in the east amply suggest that the Kunchha Thrust Sheet III in the Bheri River area was also probably covered by this thrust sheet.

The Kunchha Thrust Sheet I is tectonically superimposed over the Kunchha Thrust Sheet II in the northern part of the study area (Fig. 4). The absence of any remnants or the indications of tectonism or metamorphism, as is observed in the Sallyan Formation in the Saru Gad and Rita Khola sections indicates that this thrust sheet never extended to the southern area, but represents only a small tectonic block dragged together with the overlying Chaurjhari Thrust sheet.

The Chaurjhari Thrust Sheet comprising the Chaurjhari Group of rocks is the highest thrust sheet in the area. This is the southern extension of the main central crystalline and constitutes the western part of the Jaljala Unit of Sharma et al (1984). It rests over the Kunchha Thrust Sheet I in the present area.

\section{Structural Evolution}

From the above description, it becomes obvious that the area characteristically belongs to a thrust-belt mountain system. Evidence of large scale thrusting is provided particularly by the Chaurjhari Thrust Sheet, Kunchha Thrust Sheet II and the Nawakot Thrust Sheet. Three distinct tectonic sheets of Kunchha unit and the embrications in the Dabang and Tansen Group rocks also manifest the evidences of thin-skinned tectonism in the area.

The thin skinned tectonic model has been widely accepted by the geologists working in other major mountain systems of the world; but it is still new for the Himalayas, and particularly in the Nepal Himalaya. Gibbs (1980) briefly described the embricate stack structure in the Indian Himalaya, and proposed a hindward propagation of the embrications. Boyer and Elliot (1982) convincingly demonstrated that, in a thrust belt mountain system, the sequence of development of thrust faults must propagate from "hinterland' towards the foreland', and that the highest and the innermost thrust fault is the first to form. Elliot and Johnson (1980) have described numerous examples from the Moine Thrust belt to arrive at this conclusion. Similarly, a piggy-back sequence of thrusting has been proposed for the Alps and the Canadian Rockies (Dahlstrom, 1970; Boyer \& Elliot, 1982; Laubscher, 1985). Johnson (1986) also assumed a piggy-back evolutionary sequence in the Himalaya. In the Nepal Himalaya, Kansakar and Sharma (1986) proposed two alternative thin-skinned tectonic models for the Kali Gandaki-Burhi Gandaki region and recently, Dhital and Kizaki (1987) explained in detail the mechanism of thrusting in the northern Dang area.

\section{Thrust Fault Rules}

Thrust faults must follow certain general rules. Dahlstrom (1970) noted that thrust faults are parallel to bedding in the incompetent rocks and in the direction of transport, but cut up- section rather abruptly through the competent rocks. Various field studies, laboratory scale experiments and theoretical considerations of the rock properties support a general rule that, after the initial fracture, but before much movement, a thrust fault is always concave upwards or listric shaped (Dennis, 1967). This concave upward surface is not smooth, in fact it generally has a staircase trajectory with long flats in ductile 


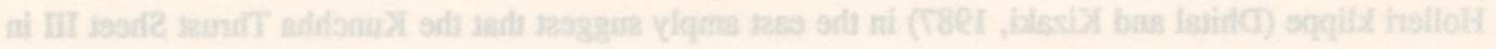

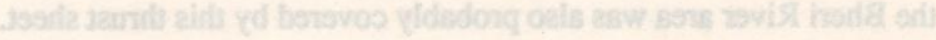
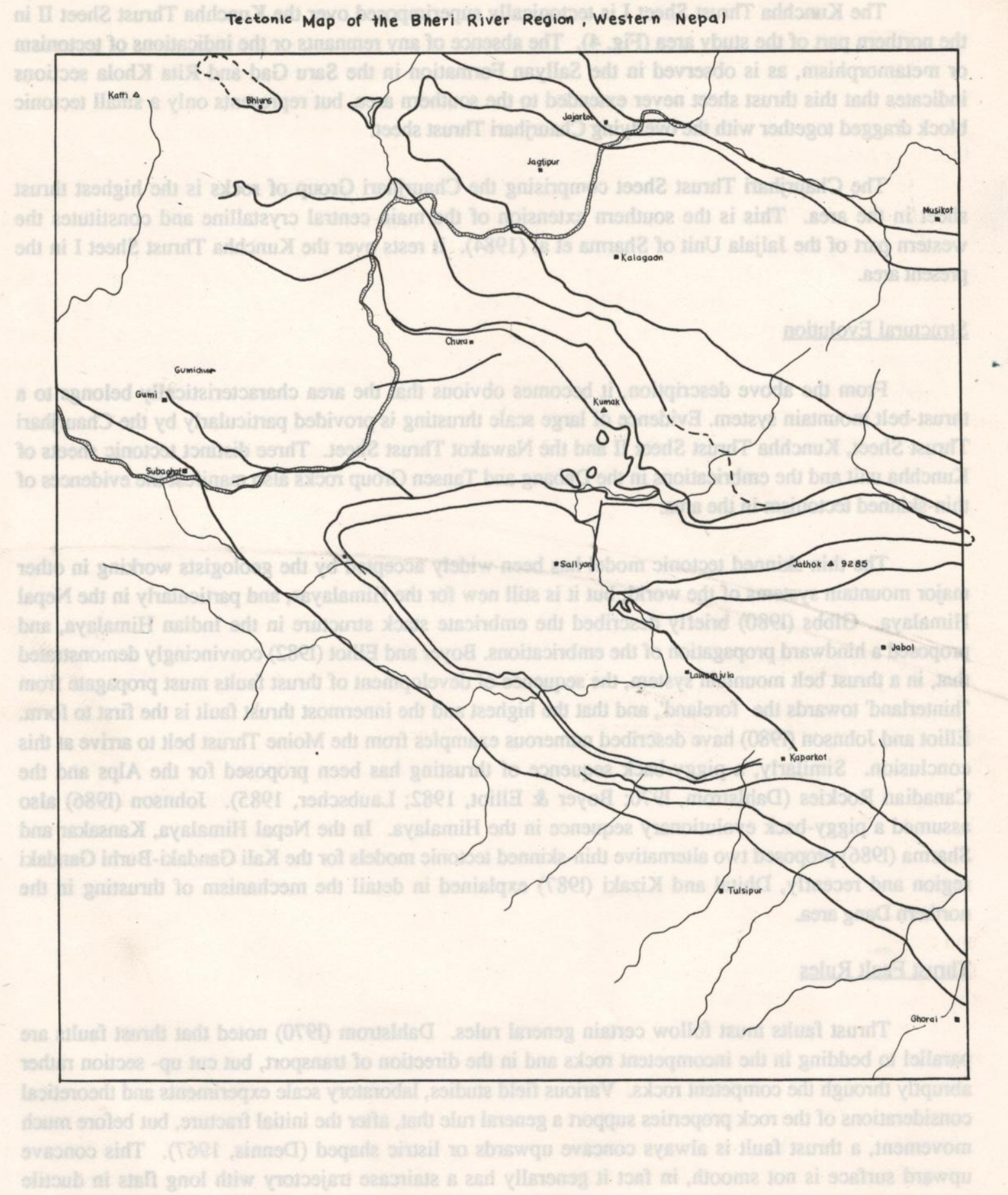
horizons and short ramps through competent units (Rich, 1934; Douglas, 1950). However, Cooper et al (1986) are of the view that thrusts may cut through the strata with smooth curved trajectories and when a thrust climbs upsection, it shows sigmoidal geometry.

The external region of an active mountain chain is usually undeformed with a sub-horizontal stratigraphic sequence until the onset of thrusting process. Thus, the thrust should never cut- down section in the direction of slip of the hanging wall, and must always put older over younger rocks. But they may cut up and down sections normal to the slip direction, and frequently, this is along the strike of the thrust fault (Elliot and Johnson, 1980).

\section{Evolutionary Sequence}

Before the onset of thrusting, the geologic situation in the Lesser Himalaya is assumed to be as shown in Fig 5a. The crystalline complex (i.e. Chaurjhari Group in the present area) constituted the basement for the Kunchha Group, which is again overlain by the Nawakot Group rocks of Late Precambrian to Early Paleozoic age. The period before the sedimentation of Daban Group in the southern belt and Gondwana Group in the north marked deep erosional phase, when erosional basins for these later sedimentation were formed (Fig. 5a). In the southern basin, sedimentation continued till OligoceneLower Miocene time, although with small depositional gaps, but in the north, the Gondwana deposit did not continue beyond Permian time.

The boundaries between Crystallines and Kunchha Groups and between the latter and the Nawakot Group, marked by incompetent rock formations, provided the initial decollement surfaces for gliding during the thrusting movements in the Himalaya. The first such glide zone generated was in the schostose layer of the Chaurjhari Formation, and the Crystalline Thrust Sheet (Chaurjhari Thrust Sheet) moved to the south along this thrust (the Main Central Thrust). The area between the M.C.T. in the north and the northern arm of the Chaurjhari Thrust in the present area is believed to constitute a duplex structure with the highest thrust (M.C.T.) as the roof thrust.

In the present area, the Chaurjhari Thrust acted as the main roof thrust for the two horses, Kunchha Thrust Sheets I and II, that constituted a duplex structure. Its sole thrust is the Kunchha Thrust II, which most probably developed along the boundary between the Kunchha Group and the underlying crystalline rocks.

As the thrusting process continued, the glide horizon cut upsection over the Nawakot sequence, and the later tectonic slippage took place along this new glide horizon, which became the sole thrust for the duplex generated within the Nawakot rocks in other sections. The Kunchha Thrust II became the roof thrust for this younger duplex. In the Bheri section, there are evidences that the former sole thrust, i.e. the Kunchha thrust at the cut-off line was not immobilised even after forming a ramp over the Nawakots.

In the Chakli Gad area, a good example of ramp structure formed by the clamping up of Nawakot rocks over the Kunchha Group rocks of Kunchha Thrust Sheet II is seen. It is indicated by oblique orientation of the underlying quartzites of Kunchha Group with respect to the overlying Nawakot Thrust Sheet and the anticlinal fold in the quartzites suggesting the upper part of a horse. Thus, it shows that 


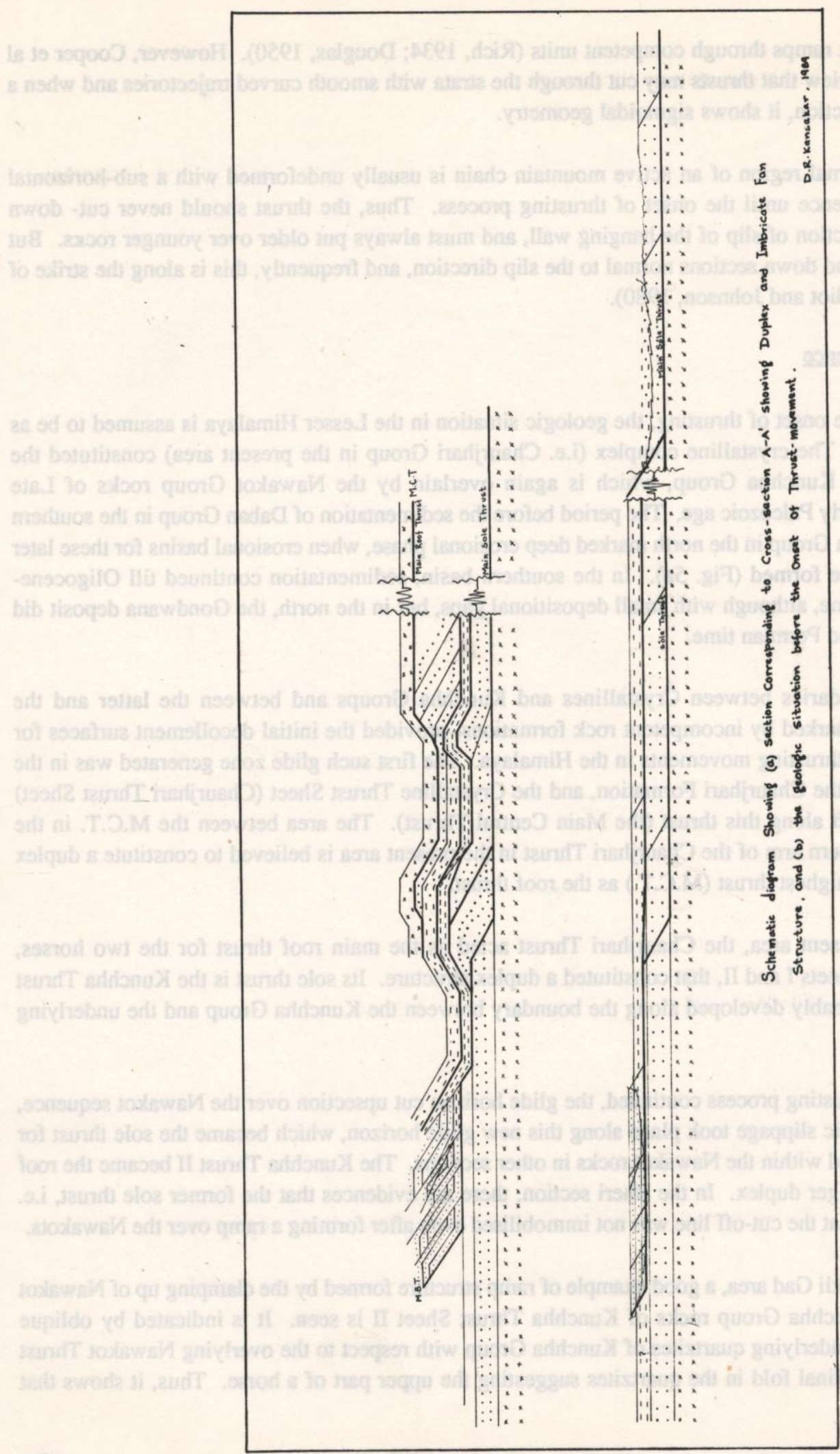


the Kunchha Thrust Sheet III originated from a much southern area as compared to the source area of the Nawakot Thrust Sheet and the higher Kunchha Thrust Sheets. Occurrence of longitudinal fault within this zone in the Bangar Khola section further suggests that the Kunchha rocks in the Surma-Arudanda section perhaps constitute two horses. For these horses, the Nawakot Thrust forms the roof thrust while the sole thrust is again the lower boundary of the Kunchha Group rocks.

The slip plane further transferred to the next higher glide zone in the later stage, when it shifted to the softer and higher Kochhap Formation in the southern sedimentary basin. During this stage, a number of embricates were developed within this sedimentary belt as the thrust mass moved south, and ultimately, they were thrusted over the Siwalik sediments along the Main Boundary Thrust, which became the main sole thrust for these embricates (compare Fig. 4 and 5 b). It seems possible that the embrications in the eastern part constitute a duplex structure as envisaged by Dhital and Kizaki (1987). But in the present area, particularly in the Bheri river section, they seemed to form embricate fan rather than a duplex. Boyer and Elliot (1982) have emphasized that "... it is possible for a duplex to change along strike into an embricate fan."

\section{CONCLUSIONS}

The Bheri River region comprises rocks of five stratigraphic groups. Except for the rocks of Gondwana Group, the other rock groups are found to be quite extensive. The area is characterised by embricate zone in the south, with the Main Boundary Thrust as the Main Sole Thrust. North of it, duplex structures predominate the tectonic construction. The incompetent basal rock members of Chaurjhari, Kunchha, Nawakot and Daban Groups provided favourable horizons necessary for the thin skinned tectonism responsible for such duplexes and embricate structures. In such cases, the thrust geometry dictates, as in other mountain systems, a piggy back sequence of thrusting in the Himalayas too.

\section{ACKNOWLEDGEMENT}

I am indebted to Mr. M. N. Rana, Director-General, Department of Mines and Geology (DMG) for giving me the opportunity to carry out this work and for kindly granting me the permission to publish it. Thanks are due to Mr. S. B. Shrestha, Chief, Regional Mapping Division, DMG for giving me encouragement. I am also thankful to Mr. T. P. Akhikari and Dr. T. Sharma for allowing me to use their results from the Jajarkot area. Mrs. I. Draxler, Geologische Bundesanstalt, Vienna, is duly acknowledged for kindly conducting palynological studies of the rock samples from the study area. Lastly, but not the least, the cooperation from Mr. G. R. Chitrakar, Geologist, DMG during the field studies is highly appreciated. 


\section{REFERENCES}

Adhikary,T.P. and Sharma T., Geological report of Marma, Chaurjhari, Jajarkot area (Far Western Nepal). Unpublished rep. Dept. of Mines and Geology (DMG), Kathmandu., pp.41, (1983).

Arita,K.,Sharma, T and Fujii, Y., Geology and Structure of the Jajarkot-Piuthan area, Central Nepal. Jour. Nepal. Geol. Soc. V.4 Special Issue, p.5-28 (1984).

Boyer, S.E. and Elliot, D., Thrust Systems. The Amer. Assoc. Petrol. Geol.Bull., V.66, NO.9, p.1196-1230, (1982).

Cooper, M.A. and Trayer, P.M., Thrust Surface Geometry: Implications for Thrust-Belt Evolution and Section-Balancing Techniques; Jour.Struct.Geol., v.8,p.305-312, (1986).

Dahlstrom, C.D.A., Structural Geology in the Eastern Margin of the Canadian Rocky Mountains. Bull.Can.Petrol.Geol.,v.18, No. 3, p. 332-406, (1970).

Dennis, J.G., International tectonic dictionary; Tulsa. Amer. Assoc. Petrol. Geol. (1967).

Dhital, M.R. and Kizaki, K., Structural Aspect of the Northern Dang, Lesser Himalaya; Bull.College of Sci., Univ. Ryukus, No. 45, p. 159-182, (1987).

Douglas, R.J.W., Callum Creek, Langford Creek, and Gap map-areas Alberta; Mem. Geol. Surv. Canada, No.225, (1950).

Elliot, D. and Johnson, M.R.W., Structural evolution in the northern part of the Moine thrust belt, NW Scotland; Trans. Royal Soc. Edinburgrgh: Earth Sciences, v.71, p69-96, (1980).

Fuchs, G. and Frank, W., Geology of west Nepal between the Rivers Kali Gandaki and Thulo Bheri; Jahrb. Geol. Bundsst. Sonderb. No. 18, p. 1-103 (1970).

Gibbs, A. D., Minor structures associated with Nappe Tectonics and stacking sequence in the SimlaKumaon-Garhwal Himalaya; in Structural Geology of the Himalaya (ed.P.S. Saklani), Today and Tomorrow's Printers and Publ. New Delhi, p. 1-15, (1980).

Hagen, T., Report on the Geological Survey of Nepal Vol. 1., Preliminary Reconnaissance., Denkschr. Schweiz. Neff. Ges., vol. LXXXVI/1, p. 1-185, (1969).

Johnson, M.R.W., The Structural Evolution of the Kumaon Lesser Himalaya; in Himalayan Thrusts and Associated Rocks, (ed.P.S. Saklani) Today and Tomorrow's Printers and Pub., New Delhi, p. 27-39, (1986).

Kansakar, D. R., Geology of Khungrichaur-Rukumkot Region in Rolpa, Piuthan and Rukum Districts, Western Nepal. Unpubl. rep. DMG, Kathmandu, pp. 75, (1982). 
Ḱansakar, D. R. and Chitrakar, G. R., Report on Geological Investigation in Dang-Sallyan Region, Western Nepal. Unpubl. rep. DMG, Kathmandu pp. 43 (1983).

Kansakar, D.R. and Chitrakar, G. R., Geology of the Bheri River Section, unpubl. rep. DMG, Kathmandu, pp.49, (1984).

Kansakar, D. R. and Sharma, T., Geology of Lesser Himalaya of Nepal between the rivers Burhi Gandaki and Kali Gandaki with special reference to structure, stratigraphy and mineral potentiality. Unpubl. rep. submitted on NCST, Kathmandu, (1986).

Kayastha, N. B. and Shrestha, R. B., Report on Detailed Geological Sections of Dang-Piuthan area, Western Nepal. Unpub. rep., DMG/PEPP, Kathmandu, pp. 36, (1982).

Laubscher, H. P., Large-scale, thin skinned thrusting in the southern Alps: Kinematic models. Geol.Soc.Amer.Bull., v. 96., p.710-718, (1985).

Rich, J.L., Mechanics of low-angle overthrust faulting illustrated by Cumberland Thrust Block Virginia, Kentucky and Tennessee. Bull.Amer. Assoc.Petrol. Geol., v 18, No.12, p.1584-1596, (1934).

Sakai, H., Geology of the Tansen Group of the Lesser Himalaya in Nepal. Memo.Fac. Sci., Kvushu Univ., Ser. D., Geol. v.XXV, No. 1, p.27-74, (1983).

Sharma, T., Kansakar, D.R. and Kizaki, K., Geology and Tectonics of the Region Between Kali Gandaki and Bheri Rivers in Central West Nepal. Bull. College Sci., Univ. Ryukus, No. 38 , p.57-102, (1984).

Sharma, T. and Kizaki, K., The Granitoid rocks of the Dailekh and the Jajarkot Regions in the Lesser Himalaya of Central West Nepal. Jour. Nep. Geol.Soc.,v.5, No. 1, p. 45-67, (1988).

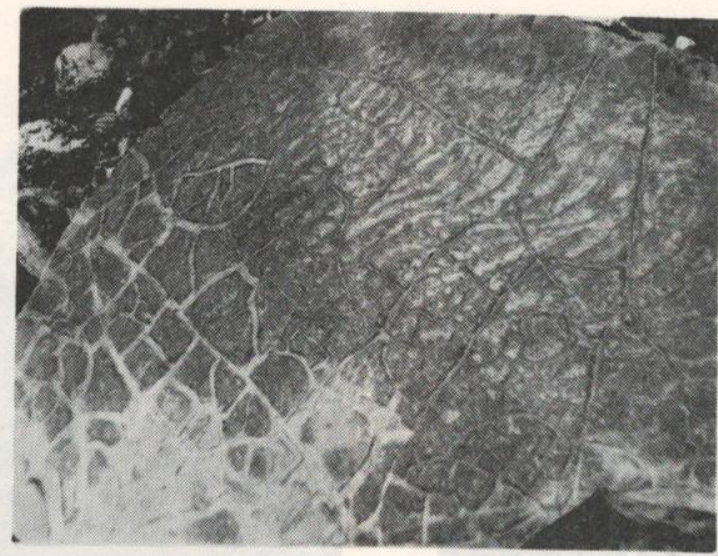

Plate 7. 


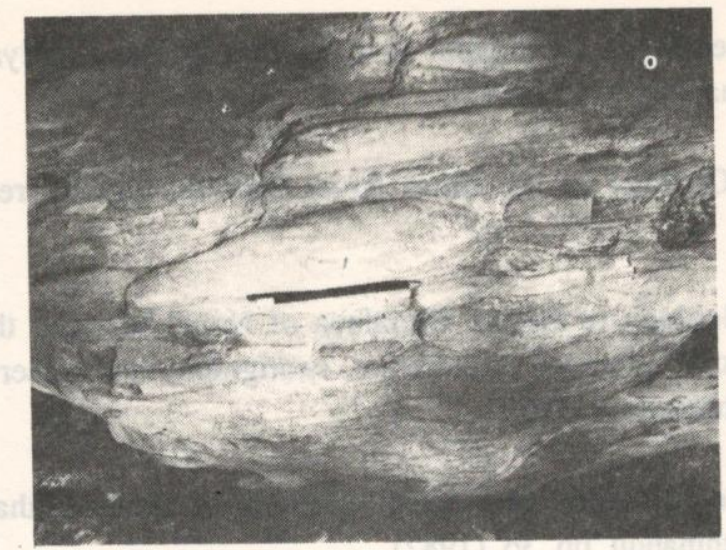

Plate 1.

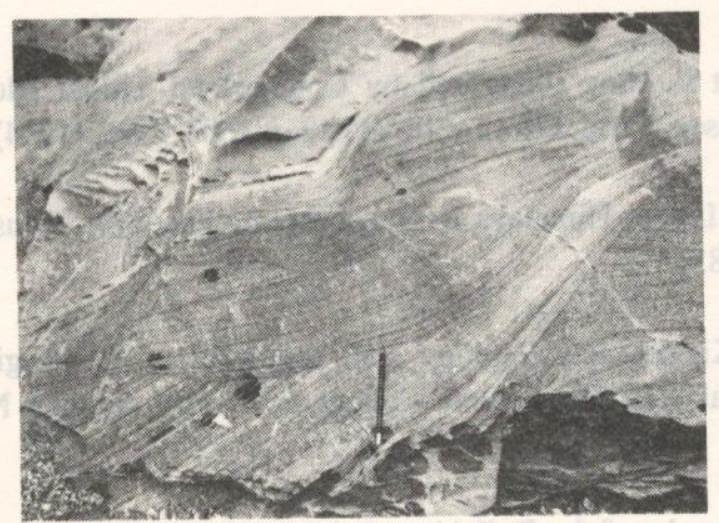

Plate 3.

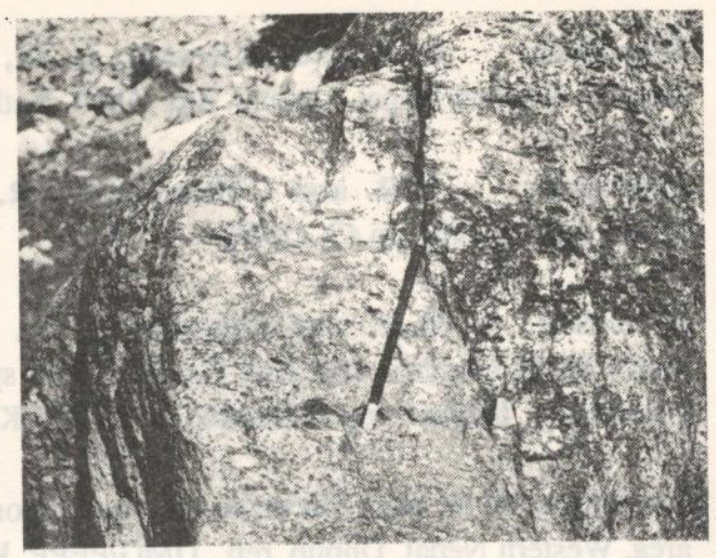

Plate 2.

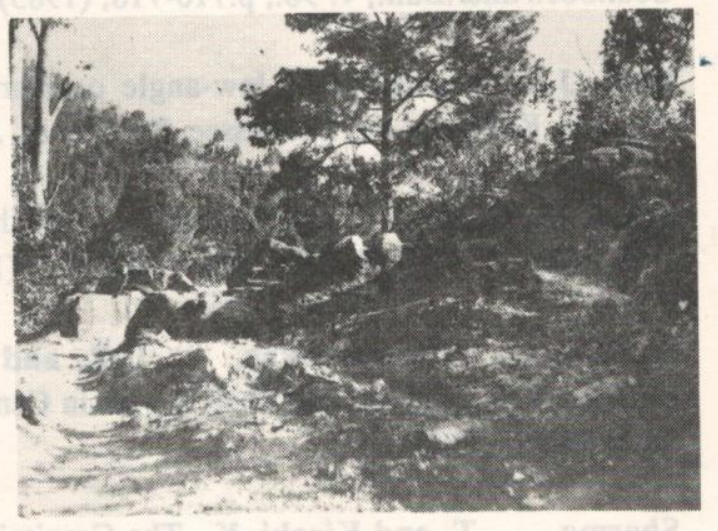

Plate 4.
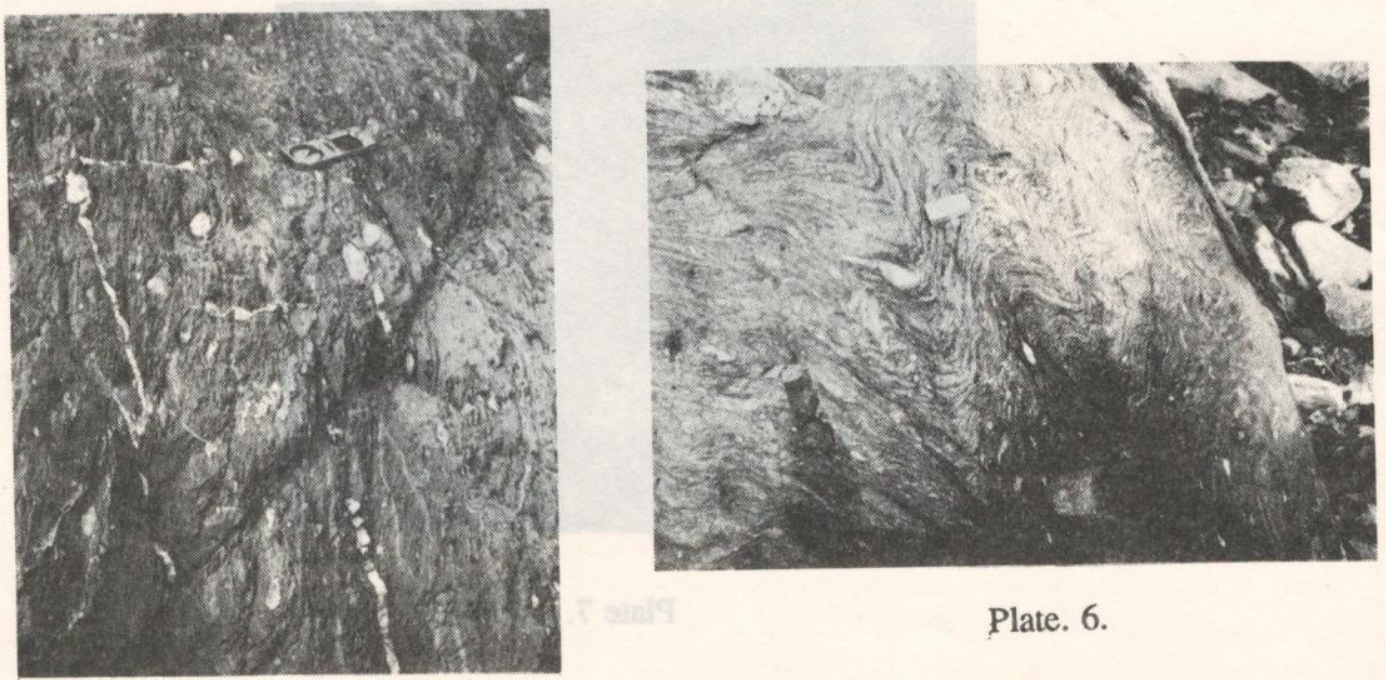

Plate. 6.

Plate 5. 